\title{
Languages of Return: Aimé Césaire and Dany Laferrière
}

\author{
Jane Hiddleston \\ Exeter College, University of Oxford \\ Jane.hiddleston@exeter.ox.ac.uk
}

\begin{abstract}
:
This article explores the multiple languages or forms of language used to imagine the return to the 'native land' in works by Aimé Césaire and Dany Laferrière. In Césaire's Cahier d'un retour au pays natal, the return is in the first place a dual movement, encapsulating both the rediscovery of Martinique on the poet's return from the métropole, and the spectre of a fantasised reconnection with Africa. And the return to Africa is never properly realised, whilst the return to Martinique, at least in the first section of the poem, is evoked with bitter disillusionment. The article analyses the languages that both evoke and create these returns in the Cahier alongside those of Dany Laferrière's L'Enigme du retour, which narrates a return to Haiti from Canada that is both immersed in Césaire and depicts a comparably complex and perhaps even more ambivalent experimentation with the languages of return. Both texts suggest that return can be dissociated from myths of origins and of the motherland to become a multifaceted and continued process of movement. And if the writing of return, and of the ongoing journey, for Césaire and Laferrière, ostensibly takes place in French, it also dissociates return from any notion of an originary mother tongue and generates an eclectic linguistic experimentation that stretches the apparently monolingual frame of the French language.
\end{abstract}

\section{Key Words:}

Language, Return, Caribbean, multilingualism, Césaire, Laferrière 
The idea of return, in critical discussion of immigration, has historically been associated with a sort of 'mythical' status. With echoes of Odysseus, 'the myth of return' has also been cited more recently in the context of the wave of immigrant workers moving to France during the 1960s and 1970s with the intention of returning to their families and homelands with their earnings. The term implies both a persistent sense of deracination, and the illusory belief that the migrant's reconnection with his or her origins is possible. As Alec Hargreaves has stressed, however, the mythical status of this conception is borne out by the multiple factors impeding the actual realisation of return. ${ }^{1}$ Yet, if we look a generation further back, for the Senegalese poet and eventual political leader Léopold Sédar Senghor, who lived in Paris as a student during the 1930s, there is a sense that poetry is nevertheless able to evoke a treasured form of originary belonging through its imagery of natural harmony and nurturing. Senghor's vision of the return to 'mother Africa' from the cold and alienating streets of Paris conjures a reassuring recovery of childhood origins: the return to the native land is also a return to the lap of the mother. In his seminal paean to the African homeland 'Femme noire', printed in the early volume 'Chants d'ombre', the poet evokes the black woman as a symbol of Africa, the giver of life and nurturer of the child, 'femme nue, femme noire / vétue de ta couleur qui est vie, de ta forme / qui est beauté, / j'ai grandi à ton ombre' ['naked woman, black woman / clothed in your colour, which is life, in your form / which is beauty / I grew up in your shadow']. ${ }^{2}$ If the poem ends with the poet's affirmation that he has the power to make this 'mother Africa' eternal, then this childhood homeland will be one in which the poem allows him to bathe in the present. It is the language of the poem, moreover, and its revivification of the nurturing body through poetic imagery, that accomplishes this reunion with the land of the poet's roots.

The poet's fantasy of return, then, can be traced and accomplished through poetry, and yet this occasioning of return through poetic creation can also turn out to be a complex process and not a linguistic rerooting. If the language of Senghor's return to Joal is bound up in the imagery of nurturing, the language evoking the journey and arrival home used by experimental writers such as Aimé Césaire, and much more recently, Dany Laferrière, takes many different and eclectic forms, which together aptly debunk the 'myth of return' and its

\footnotetext{
${ }^{1}$ For more on immigration in France and the myth of return, see Alec G. Hargreaves, Multi-Ethnic France: Immigration, Politics, Culture, and Society, $2^{\text {nd }}$ Edition (New York: Routledge, 2007). Hargreaves notes that whilst there was pressure particularly through the 1970s and 80s on immigrants to be repatriated, many immigrants and their families were by this time settled in France and returning to the putative native land was impracticable.

${ }^{2}$ Léopold Sédar Senghor, 'Femme noire', in 'Chants d'ombre', Euvre poétique (Paris : Seuil, 1990) pp. 18-19. My translation.
} 
attendant association with cultural belonging. Their 'languages of return' can be construed, then, as the multiple styles, sets of imagery, and lexicons that they juxtapose with one another in a variegated text that also mingles verse and prose, and that serves to dramatise the many movements and layers that shape their conceptualisation of a return to a putative homeland. Aimé Césaire's return in the Cahier d'un retour au pays natal, first published in 1939, for example, deploys an explosion of different forms of language - different lexicons, rhythms, and types of images conceived to multiple different effects - quite distinct from the more culturally and ethnically grounded language of Senghor. Both create the return through poetic language, but whereas for Senghor, at least in the early poems of 'Chants d'ombre', that language, perhaps paradoxically given his use of French, is one of a movement back to a single origin, in Césaire's poem the return requires an experimentation with a multitude of different registers and linguistic forms. The return for Césaire, moreover, is a dual movement, encapsulating both the rediscovery of Martinique on the poet's return from the métropole, and the spectre of a fantasised reconnection with Africa. And the return to Africa is never properly realised, whilst the return to Martinique, at least in the first section of the poem, is evoked with bitter disillusionment.

This article will explore the languages that both evoke and create these returns in Césaire's Cahier alongside those of Dany Laferrière's L'Enigme du retour, published more recently in 2009. Laferrière's novel evidently contains elements of its author's own musings on the experience of return, and narrates the writer-protagonist Dany's return to Haiti from Canada in a form that is both immersed in Césaire and depicts a comparably complex and, in the end, even more ambivalent experimentation with the languages of return. Laferrière's focus on Haiti after successive dictatorships and after a prolonged absence at the same time contrasts with Césaire's desired return as a leader figure, determined to improve living conditions for his people after a briefer absence during the pre-war period. Laferrière's return remains as a result alienated throughout the text, despite the poet's determined embrace of the sounds of the local environment. Also, although Césaire's language is both more diverse and more taxing, Laferrière's much later reflection on the return to Haiti betrays an increased self-consciousness of the detachment that the writing of return necessarily brings. Both texts nevertheless suggest that return can be dissociated from the mythologisation described above: for both writers it is presented as textual experiment, and, moreover, one that requires the juxtaposition of different forms of language and which will also never be fully and definitively achieved. And if the writing of return and of the ongoing journey for Césaire and Laferrière ostensibly takes place in French, it also dissociates return from any notion of an 
originary mother tongue and generates an eclectic linguistic experimentation that stretches the apparently monolingual frame of the French language.

Senghor's idealised return to Africa can be contrasted with Edouard Glissant's condemnation of the regressive nature of the 'Retour'. In Le Discours antillais, Glissant insists, 'le Retour est l'obsession de l'Un; il ne faut pas changer l'être. Revenir, c'est consacrer la permanence, la non-relation' ['Reversion is the obsession with a single origin: one must not alter the state of being. To revert is to consecrate permanence, to negate contact']. ${ }^{3}$ In the place of this retrogressive return, Glissant proposes a 'Détour', a roundabout movement which, if it leads anywhere, it is to the 'point d'intrication', the 'point of entanglement' of the multiple influences that shape being as Relation. Césaire and Laferrière's poetic narratives of return work uncertainly between the models of Senghor and Glissant. Both retain a longing for return, but they figure that process as a multidirectional journey accomplished through multiple kinds of language, and with varying conceptions of the relationship between language and place. While both Césaire and Laferrière at times, like Senghor, imagine a poetic language able to communicate with and return the poet to the natural world, to the earth, they also both reject the myth of originary belonging in the land and embrace the dissonant and eclectic sounds of the Martinican or Haitian city. And if it might be tempting to see in this contrast between the language of nature and that of the city a concomitant dichotomy between idyllic fantasy and gritty reality, between what both have referred to as the 'pays rêvé' and the 'pays réel', both Césaire and Laferrière finish by undermining this opposition, so that the poetic return is capable of embracing the urban and the rural, reality and the imagination, at the same time. The return figured by Césaire and Laferrière combines the language of nature with the language of the city, and juggles multiple sounds, registers, and idioms in a variegated linguistic blending that captures all the complexity of the movement of return. While they only sparsely refer to creole languages, their eclectic and experimental French unravels the association between language, identity and rootedness in the context of the poetry or narrative of return.

\footnotetext{
${ }^{3}$ Edouard Glissant, Le Discours antillais (Paris: Gallimard, 1997) p. 44 ; Caribbean Discourse: Selected Essays, trans. J. Michael Dash (Charlottesville : University Press of Virginia, 1999) p. 16.
} 


\section{Aimé Césaire: Cahier d'un retour au pays natal}

The arresting opening of Césaire's Cahier portrays the poet's return to Martinique to discover a miserable dystopia. The evocation of the city of Fort-de-France is crammed with imagery of rotting, stagnation, decay, and disease, as well as with the traces of a long history of violence. The native land has nothing here of Senghor's nurturing Africa, and also debunks myths of the exotic island, where the lyric subject would be immersed seamlessly and harmoniously in the land, popular with poets like Baudelaire. This dystopic return, however, is clearly a linguistic experience. On the one hand, it is a response to the poet's observation that the city to which he returns has been silenced by years of oppression. Poverty has generated stagnation and apathy, and has deprived people of the strength to speak out: 'une vieille misère pourrissant sous le soleil, silencieusement; un vieux silence crevant de pustules tièdes' ['an old poverty rotting under the sun, silently; an old silence bursting with tepid pustules']. ${ }^{4}$ On the other hand, however, the poet challenges this silencing in his brazen assumption of a combative poetic voice, with its own expansive idiom and a bold insistence on its own power. The very start of the poem is an assumption of speech in the form of an aggressive challenge, conveyed in slang words, 'va-t-en, lui disais-je, gueule de flic, gueule de vache, va-t-en je déteste les larbins de l'ordre et les hannetons de l'espérence' ['get lost I said you cop face, you pig face, get lost, I hate the flunkies of order and the cockchafers of hope']. ${ }^{5}$ The overt challenge is not present in Césaire's original 1939 version of the poem, but is part of the crystallisation of the poet's collusion of poetry with revolt in the more politically inflected version of $1956 .{ }^{6}$ The language of return here is an at once colloquial and lexically highly inventive insult to authority, an abrupt challenge to both silencing and stereotyping, in a register resonant at once with street slang and with literary poetics: A. James Arnold notes Césaire's nod to Lautréamont in the use of the apostrophe here. ${ }^{7}$ Out of the 'échouage hétéroclite' ['disparate wreckage'] of the city, the poet conjures a furious and verbose riposte to centuries of oppression, as images of brutality and sickness pile on top of one another in an extraordinary profusion of often unusual or even fabricated words in all registers. Césaire's defiant return is enacted in this linguistic tour de force, that details the monstrosities created

\footnotetext{
${ }^{4}$ Aimé Césaire, Cahier d'un retour au pays natal, trans. Mireille Rosello (Newcastle-upon-Tyne: Bloodaxe Books, 1995) p. 72; p. 73.

${ }^{5}$ Ibid., p. 72 ; p. 73.

${ }^{6}$ For a bilingual edition and discussion of the differences between the two versions, see A. James Arnold and Clayton Eshleman's Aimé Césaire, The Original 1939 Notebook of a Return to the Native Land, (Middletown, Connecticut: Wesleyan University Press, 2013).

${ }^{7}$ James A. Arnold, Modernism and Negritude: The Poetry and Poetics of Aimé Césaire , (Cambridge, MA: Harvard University Press, 1981).
} 
and silenced by colonial authority: 'la parade des risibles et scrofuleux bubons, les poutures de microbes très étranges, les poisons sans alexitère connu, les sanies de plaies bien antiques, les fermentations imprévisibles d'espèces putrescibles' ['the parade of ridiculous and scrofulous buboes, the cultures of bizarre germs, the poisons with no known alexiteric, the sanies of very ancient wounds, the unpredictable fermentations of rotting species']. ${ }^{8}$

The disillusioned rediscovery of the Martinican city is juxtaposed, however, with intermittent calls for a return to the natural environment. The journey back to Martinique engenders at the same time a journey of the mind to connect with the elements of the natural world, a return to a land ' - mille fois plus natale et dorée d'un soleil que n'entame nul prisme - la terre où tout est libre et fraternel, ma terre' ['a thousand times more native and turned to a golden tan by a sun that no prism divides - a land where everything is free and fraternal, my land']. ${ }^{9}$ In a language now ironically reminiscent of Baudelaire's 'L'Invitation au voyage', where the sun too clothes countryside and city in gold, Césaire conjures a vision of the originary homeland in a contrast with that of which slaves in the Caribbean were dispossessed. ${ }^{10}$ This is not just a question of a different kind of imagery, however, but a call for a poetic language that would seize, embrace, and incorporate the dynamism and effervescence of the landscape. The poet does not merely invoke a rural as opposed to an urban setting, but affirms his ability to speak the language of nature, to perform his fusion with the environment in his speech: 'je retrouverais le secret des grandes communications et des grandes combustions. Je dirais orage. Je dirais fleuve. Je dirais tornade. Je dirais feuille. Je dirais arbre.' ['I would rediscover the secret of great communications and of great combustions. I would say storm. I would say river. I would say tornado. I would say leaf, I would say tree.' $]^{11}$ The return to nature is a poetic dream, and, as Abiola Irele suggests, launches the poet's revolt in earnest, since the connection with the world of nature promises universal renewal. ${ }^{12}$ This affirmation of the integration of man, nature, and the cosmos is a central preoccupation, moreover, of Césaire's theoretical reflection in 'Poésie et connaissance', where man is indeed equated with the universe itself ('l'homme n'est pas

\footnotetext{
${ }^{8}$ Aimé Césaire, Cahier d'un retour au pays natal, p. 76 ; p. 77. For an eloquent account of Césaire's use of hyperbole in this section, see Natalie Melas, All the Difference in the World: Postcoloniality and the Ends of Comparison (Stanford: Stanford University Press, 2007).

${ }^{9}$ Ibid., p. 86 ; p. 87.

${ }^{10}$ Charles Baudelaire, 'L'Invitation au voyage', Les Fleurs du Mal (Paris: Flammarion, 1991). 'Les soleils couchants / Revêtent les champs, / Les canaux, la ville entière, / D’hyacinthe et d'or.' See p. 100.

${ }^{11}$ Aimé Césaire, Cahier d'un retour au pays natal, p. 86.

12 See Abiola Irele's commentary in his edition to the Cahier d'un retour au pays natal (Ohio State University Press, 2000) p. 62.
} 
seulement l'homme. Il est univers') ['man is not only man. He is the universe']. ${ }^{13}$ In the Cahier, however, the poet aspires specifically to find the language that would wed the poet with the elements of the distant homeland, so that ' $\mathrm{j}$ ' aurais des mots assez vastes pour vous contenir' ['I would have words vast enough to contain you']. ${ }^{14}$ Poetry itself would create that longed-for connection, though again, this is not so much in a return to the comforting lap of the 'motherland', but in an acceptance and embrace of what Césaire evokes as the virile agency and power of the land far beyond the attempts of man to control it: 'terre grand sexe levé vers le soleil / terre grand délire de la mentule de Dieu / terre sauvage montée des resserres de la mer avec dans la bouche une touffe de cécropies' ['land great organ rising towards the sun / land great delirium of God's mentula / wild land risen from the sea's storehouses with a clump of cecropias in your mouth']. This primordial reunion between poet, language, and the earth recurs throughout the poem to reach an apotheosis at the end, as the poet calls, 'lie ma noire vibration au nombril même du monde' ['bind my black vibration to the very navel of the world']. ${ }^{15}$

On one level, Césaire's evocation of a language immersed in the natural world, both capable of communicating with it and mindful of its perennial power, might be conceived to recall something of Baudelaire's language of 'correspondances'. In 'Correspondances', Baudelaire famously figures man passing through the 'forêt de symboles' ['forest of symbols'], able to interpret the meaning of the natural world and participating in its own communicative language, where 'les parfums, les couleurs et les sons se répondent' ['perfumes, colours and sounds answer one another']. ${ }^{16}$ As Jonathan Culler has suggested, Baudelaire may here be subtly questioning the dream of poets such as Lamartine and Hugo for a language that would perfectly capture the natural world to which it refers, yet he is certainly reflecting on that ideal of a primordial communication. ${ }^{17}$ Césaire's assertion of the poet's utterance of natural features appears, then, to chime with a comparable vision of a language at one with the world rather than a dissonant and arbitrary structure awkwardly imposed upon it. Césaire's call to the elements, however, is far less one that caters to the

\footnotetext{
${ }^{13}$ Aimé Césaire, 'Poésie et connaissance', Lilian Kesteloot et Barthélémy Kotchy, Aimé Césaire: l'homme et l'œuvre (Paris: Présence Africaine, 1973) p. 118. I also discuss the universalism in this essay and elsewhere in Césaire in my Decolonising the Intellectual: Politics, Culture, and Humanism at the End of the French Empire (Liverpool: Liverpool University Press, 2014).

${ }^{14}$ Aimé Césaire, Cahier d'un retour au pays natal, p. 86 ; p. 87.

${ }^{15}$ Ibid., p. 134 ; p. 135.

${ }^{16}$ Charles Baudelaire, 'Correspondances', Les Fleurs du Mal, pp. 62-3.

${ }^{17}$ Jonathan Culler, 'Intertextuality and Interpretation: Baudelaire's 'Correspondances', in Christopher Prendergast (ed.), Nineteenth-century French Poetry: Introductions to Close Reading (Cambridge: Cambridge University Press, 1990) pp. 118-137.
} 
solitary lyric poet's spiritual musings, than one that seeks to record his immersion in an elemental environment over which he is in no way sovereign. Moreover, ecocritics such as Elizabeth Deloughrey have examined the ways in which the Caribbean in particular is a region that has been 'radically altered in terms of human and botanic migration, transplantation, and settlement', and one where the myth of a return to an unmediated state of nature is most starkly contrasted with the violence imposed upon the landscape through the plantation system. ${ }^{18}$ The task for Caribbean writers, suggest Deloughrey et al, is to figure rather the integration between natural and social human history, in a challenge both to colonial claims to mastery and, conversely, to myths of an untouched, idyllic, Edenic paradise. Literary writers such as Césaire both seek to give agency back to the landscape and to record the human's immersion in it as well as his apprehension of its unfathomable power, figured throughout Césaire's work most ostensibly through the figure of the volcano, in an implicit critique of his attempts at domination. The poet's return to the natural environment is at once an aspiration for a language that would voice that integration, and an evocation of humanity's fragility and dependence on the earth.

The journey operated by the Cahier, however, is in no way simply a movement back; rather, the return demands at the same time a broader circulation, an ongoing recollection of black history in different parts of the world. The stultified and constricted island will be better known through rediscovery of its situation in the wider world, as 'mon île non-clôture' now looks outwards, 'sa claire audace debout à l'arrière de cette polynésie' ['my non-enclosure island, its clear boldness standing at the back of this Polynesia.'] ${ }^{19}$ The island stands up for itself, just as Haiti did in the first slave revolt, and recalls parallel histories of oppression in Florida and Africa. As Césaire redraws the map so as to figure the history of relations between the Caribbean, Europe and America, moreover, he also emphasises both the exploitation of black people across the world and their lasting influence. A proper 'return' to the Martinican people would record this history of diaspora, of displacement as well as interconnection, 'et je me dis Bordeaux et Nantes et Liverpool et New York San Francisco / pas un bout de ce monde qui ne porte mon empreinte digitale' ['and I tell myself Bordeaux and Nantes and Liverpool and New York and San Francisco / not a piece of this world that does not bear my fingerprint']. ${ }^{20}$ Once again, however, the poet's global journey is a

\footnotetext{
${ }^{18}$ Elizabeth Deloughrey, Rénée K. Gosson, George B. Handley, 'Introduction', in Elizabeth Deloughrey, Rénée K. Gosson, George B. Handley (eds.), Caribbean Literature and the Environment: Between Nature and Culture (Charlottesville: University of Virginia Press, 2005), pp.1-30 (p. 1).

${ }^{19}$ Aimé Césaire, Cahier d'un retour au pays natal, p. 90 ; p. 91.

${ }^{20}$ Ibid., p. 90 ; p. 91.
} 
linguistic act. It records the silencing of past slave revolts in Southern American states, 'Virginie. Tennessee. Géorgie. Alabama', the 'trompettes absurdement bouchées' ['trumpets absurdly clogged up'], and notes the black man's trace or 'imprint' in the ports cited above, 'mon calcanéum sur le dos des gratte-ciel et ma crasse dans le scintillement des gemmes!' ['my calcaneus on the backs of skyscrapers and my filth in the glitter of gems !']. ${ }^{21}$ The journey undertaken through the rest of the Cahier is preceded, then, by a promise that the poet will achieve through his wandering the creation of a new voice. He imagines this time not a desperate riposte in street language, like that with which the poem opened, but the more noble oration of a leader, as if, again like Odysseus, he returns to claim his luminary status at home: 'je viendrais à ce pays mien et je lui dirais: «Embrassez-moi sans crainte... Et si je ne sais que parler, c'est pour vous que je parlerai»' ['I would come to this land of mine and I would say: 'Kiss me without fear... And if I can only speak, it is for you that I shall speak']. ${ }^{22}$ His speech will record the black man's cries of pain, moreover, and will accord his language with a new power to call for change. His words will not have the clumsy heaviness of 'un ours qui danse' ['a dancing bear'], but will lead the revolt in solidarity. Césaire is referring here to Flaubert's famous 'chaudron fêlé', the cracked container evoked in Madame Bovary, where 'nous battons des mélodies à faire danser les ours' ['we knock out tunes for dancing-bears'], though here Flaubert's image of a faulty, cumbersome and inelegant language is replaced by a vision of linguistic power. ${ }^{23}$

The rest of the Cahier invents and explores different kinds of language with which to articulate the revolt of black people both in Martinique and across the world. Having refigured return as multidimensional and as a new departure, Césaire goes on to experiment with multiple forms of language in which to voice the defiance of the people with whom he wants to reconnect. These various forms are also so many ways of conceptualising poetic language through association with other kinds of usage (language is revolt, it is sorcery, prayer, or dance), and the poet both theorises and dramatises the power of the poetic return through analogy with these other forms of expression. Some of these, as Gregson Davis argues, can be conceived as 'speech acts', forms of language that can themselves bring their

\footnotetext{
${ }^{21}$ Ibid., p. 90; p. 91. This imagery of the journey to America can also be read as a demonstration of Césaire's engagement with Black American poets and thinkers such as Langston Hughes and Claude McKay. For more information on this see Brent Hayes Edwards, The Practice of Diaspora: Literature, Translation, and the Rise of Black Internationalism (Cambridge: Harvard University Press, 2003).

${ }^{22}$ Aimé Césaire, Cahier d'un retour au pays natal, p. 86 ; p. 87.

${ }^{23}$ Gustave Flaubert, Madame Bovary (Paris: Livre générale française, 1972) p. 226; Madame Bovary, trans. Geoffrey Wall (London: Penguin, 1992) p. 177.
} 
referents into being or bring about change. ${ }^{24}$ Intermittent assertions of linguistic power, however, such as the apparently confident citation, "«ma bouche sera la bouche des malheurs qui n'ont point de bouche»' ['my mouth will be the mouth of those griefs which have no mouth'], are juxtaposed with admissions of frailty, again suggesting that linguistic experimentation, the tentative adoption of different forms, will express the poet's multifaceted experience of return better than the illusion of an originary mother tongue that would unite the nation and speak for all. ${ }^{25}$ Césaire's eclectic languages of return at the same time reject the monolithic language of reason, the assumption that rational argument could provide a way out of the black man's silencing, and his imagery is often both lexically obscure and deliberately incongruous.

One of the languages of the poet's revolt, then, will be the language of madness, 'la folie qui se souvient / la folie qui hurle / la folie qui voit / la folie qui déchaîne' ['the madness that remembers / the madness that screams / the madness that sees / the madness that is unleashed']. ${ }^{26}$ If the coloniser used the language of reason to justify his denigration of the black man, then it is irrevocably associated with violence, 'il m'est corolle du fouet' ['it is the whip's corolla']. ${ }^{27}$ Fanon may have seen in Césaire's rejection of reason a dangerous complicity with stereotypical assumptions of the black man's intellectual incompetence, but irrational language in the Cahier is also another force for resistance. ${ }^{28}$ It is a rejection of existing forms of public and political discourse, a revolt against the status quo in linguistic form. It is, moreover, a knowing language, one 'qui se souvient', that records the history of oppression, and it is also a language of transformation. Césaire's imagery teeters here between inanity, 'que 2 et 2 font 5 / que la forêt miaule'['that 2 and 2 make 5 / that the forest mews'], and conversely, a series of expressions of defiance: 'j'ai porté des plumes de perroquet des dépouilles de chat musqué / J'ai lassé la patience des missionnaires / insulté les bienfaiteurs de l'humanité. / Défié Tyr. Défié Sidon. / Adoré le Zambèze. / L’étendue de ma perversité me confond!' ['I have worn parrot-feathers and musk-cat skins / I have tried the patience of missionaries / insulted the benefactors of humankind. / Defied Tyre. Defied

\footnotetext{
${ }^{24}$ See Gregson Davis, 'Negritude-as-Performance: The Interplay of Efficacious and Inefficacious Speech Acts in Cahier d'un retour au pays natal', Research in African Literatures 41.1, Special Issue: Aimé Césaire, 19132008: Poet, Politician, Cultural Statesman (2010): 142-154.

${ }^{25}$ Aimé Césaire, Cahier d'un retour au pays natal, p. 88 ; p. 89.

${ }^{26}$ Ibid., p. 92 ; p. 93.

${ }^{27}$ Ibid., p. 92 ; p. 93.

${ }^{28}$ See Fanon's comments on Césaire's poetry in Peau noire, masques blancs (Paris: Seuil, 1995). The relationship between the rational and the irrational in Fanon's readings of Césaire is discussed in my own 'Fanon and the Uses of Literature', Nottingham French Studies 54.1 (2015): 38-51.
} 
Sidon. / Adored the Zambezi. / The extent of my perversity confounds me!']. ${ }^{29}$ If the poet defies the great Phoenician city states of Tyre and Sidon, this can be read as an expression of resistance to such dominant commercial trade centres, and his adulation of the Zambezi river again connotes a reuniting with the African land. Statements such as these also create a chaotic jumbling up of places and customs, associated here for the poet with madness perhaps as a result of their strangeness and incongruity, but which dramatise linguistic agility and unpredictability. If they are rather more sophisticated than Fanon's scepticism suggested, however, the admission of their 'perversite' also perhaps betrays the poet's awareness of the uncertain status of his eclectic linguistic experiment.

As the poet girds his strength, and as the poem moves towards its conclusion, the lexically diverse and challenging language is given increasing power. The poet becomes a sorcerer in that he conjures a series of symbols of rebellion and resilience from the natural world, as if in naming this eclectic succession of animals and elements he can enjoin the world to contribute to the uprising. Césaire's linguistic sorcery is worth quoting at length:

vienne le colibri

vienne l'épervier

vienne le bris de l'horizon

vienne le cynocéphale

vienne le lotus porteur du monde

vienne de dauphins une insurrection perlière brisant la coquille

de la mer vienne un plongeon d'îles

vienne la disparition des jours de chair morte dans la chaux vive

des rapaces viennent les ovaires de l'eau où le futur agite ses

petites têtes

viennent les loups qui pâturent dans les orifices sauvages du corps

à l'heure où à l'auberge écliptique se rencontrent ma lune et ton soleil. ${ }^{30}$

['May the hummingbird come

come the sparrow-hawk

come the horizon-shatter

\footnotetext{
${ }^{29}$ Aimé Césaire, Cahier d'un retour au pays natal, p. 94 ; p. 95.

${ }^{30}$ Ibid., p. 112; p. 113.
} 
come the cynocephalus

come the lotus, bearer of the world

come from dolphins a pearl insurrection shattering the shell of the sea

come a plunging of islands

come the disappearance of days of dead flesh in the quicklime of predators

come the ovaries of the waters where the future wriggles its tiny little heads

come wolves grazing in the savage orifices of the body at the hour

when at the ecliptic inn my moon meets your sun.']

Brent Hayes Edwards has commented on Césaire's frequent use of anaphora in the Cahier, arguing that the repetition also brings about transformation, and these lines are an apt example. ${ }^{31}$ The listing of these diverse creatures and landscapes brings them onto the poetic scene as if to involve them in the uprising, and the poet's chant here is reminiscent of a call to battle addressed to a dynamic and eclectic animal kingdom. The lexical choices the poet makes are also significant: the hummingbird represents determination, whilst the sparrowhawk presages death (it circulates round the dying Toussaint Louverture earlier in the poem). The shattering of the horizon connotes the destruction of the old and the advent of the new, the cynocephalus (a dog-headed man) combines the human with the animal world, the lotus promises creation, and the insurrection emerging from the pearl is a sweeping away of past violence ('jours de chair morte'). The natural landscape, moreover, is described with the vocabulary of human reproduction, and the poet's summoning of all these features promises rebirth through that very invocation.

From sorcery, the poet moves to prayer and prophecy, further instances of language with heightened power. The poetic voice beseeches, 'donnez-moi la force sauvage du sorcier / donnez à mes mains puissance de modeler / donnez à mon âme la trempe de l'épée' ['give me the savage faith of the sorcerer / give my hands the power to mould / give my soul the temper of the sword'], and the form of address here seems to invoke a higher power capable of bringing about change. ${ }^{32}$ The image of the poet's hands remodelling is also a metaphor for the poem as a process of recreation rather than a simple return to a former state. It is through this 'prière virile' that the poet moulds himself into the figure of a kind of messiah, the bringer of rebirth, and also as the leader of the people to whom he returns. If the prayer will

\footnotetext{
${ }^{31}$ See Brent Hayes Edwards, 'Aimé Césaire and the Syntax of Influence', Research in African Literatures 36.2 (2005): 1-18.

${ }^{32}$ Aimé Césaire, Cahier d'un retour au pays natal, p. 116 ; p. 117.
} 
bring him 'les muscles de cette pirogue sur la mer démontée / et l'allégresse convaincante du lambi de la bonne nouvelle' ['give me the muscles of that pirogue on the raging sea / give me the convincing cheerfulness of the lambi bearing good news'], it is through this speech act that he will finally accomplish the return promised by the poem's title. ${ }^{33}$ If the poet is here the controller of the ship, then it might also be he who will lead the slave uprising at the poem's climax, where the black man finally sails not in captivity but 'debout / et / libre'. ${ }^{34}$ The poet here is transformed into a prophet and a revolutionary, returning now as the captain of his people rather than as the disgusted and disillusioned expatriate he represented at the beginning.

Yet Césaire's poetic performance of the leader's return is not always as confident as this imagery would suggest. If he questioned the power of words in his denunciation of colonial reason ('des mots?'), he also questions the power of poetry by finishing on a sense of incompletion: 'il y a encore une mer à traverser / oh encore une mer à traverser' ['there is one more sea to cross / oh, one more sea to cross']. ${ }^{35}$ The form of these lines is reminiscent of a slave song, and yet Césaire wonders if the captain of the ship is also really the representative of the people, and whether his words will succeed in bringing the solidarity and revolution he desires. Is he 'le maître des rires? / le maître du silence formidable? / le maître de l'espoir et du désespoir ? / Le maître de la paresse ? / Le maître des danses ?' ['the master of laughs? / The master of formidable silence? / The master of hope and despair? / The master of laziness? The master of dances?]. ${ }^{36}$ If he might be the one who choreographs the people's rebellion, however, perhaps his poetry might also fail to communicate, its languages might end up ringing hollow. The image of the 'maitre du silence', moreover, refers to Rimbaud's confession of disillusionment at the end of 'Enfance' in Illuminations, where visions of the poet as saint, as wise man, and as child give way to the realisation of the inadequacy of the verbal inscription of the images of change harboured by the poet as visionary. Earlier in the Cahier, the poet confessed to joining in with the laughter of the women on the tram who mock the downtrodden 'nègre', 'COMIQUE ET LAID', like Baudelaire's albatross limping on land. And perhaps these references to French poets, the borrowing of their language and imagery, too divorce his language from that of the Creole-speaking Martinicans to whom he is trying to return.

\footnotetext{
${ }^{33}$ Ibid., p. 118; p. 119.

${ }^{34}$ Ibid., p. 130; p. 131.

${ }^{35}$ Ibid., p. 132; p. 133.

${ }^{36}$ Ibid., p. 132; p. 133.
} 
If the closing pages of the Cahier convey the self-assurance of the poet, his belief in the success of his language in bringing about revolution, the intermittent lack of confidence remains crucial to Césaire's linguistic experiment. The poet suggests that no single language or idiom could either return him to the putative homeland or bind him unproblematically with the Martinican people. And if Raphaël Confiant, for example, lamented that Césaire does not draw enough on Creole language and culture, it should be remembered that he in no way believed he could speak for the Creole community, and the Cahier is an amalgam of idioms and registers rather than a testimony to a particular tradition. ${ }^{37}$ The imagery of dance in the final section captures something of the diversity Césaire is trying to record, as it represents a liberated and provisional form of self-expression, that of multiple irreverent black men. The poet affirms, 'à moi mes danses / mes danses de mauvais nègre / à moi mes danses / la danse brise-carcan / la danse saute-prison / la danse il-est-beau-et-bon-et-légitime-d'être-nègre' ['come to me my dances / my bad nigger dances / come to me my dances / the breaking-theyoke dance / the jump-jail dance / the it-is-beautiful-and-good-and legitimate-to-be-a-nigger dance']; ${ }^{38}$ the dance, like the poet's language, might take many forms, but it will express selfcreation and the throwing off of constraint. Like the poet's own languages, the dances will be diverse, invented forms of expression, resistant to sanctioned convention just as the poem constantly makes unusual lexical choices, mixes incongruous imagery, and represents linguistic activity in multiple different forms. French sources are mingled with forms and rhythms taken from African traditions as well as contemporary African American practices, and Césaire's vital languages are construed to invoke different forms of power.

The closing line, 'je veux pêcher maintenant la langue maléfique de la nuit en son immobile verrition' [I now want to fish the night's malevolent tongue in its immobile revolvolution!'] is rich in its suggestiveness for the present reflection on language. It can be construed to indicate a calling up of new languages out of a tabula rasa, since, as J. Michael Dash demonstrates, the term 'verrition' is based on the Latin 'verri', to sweep, to scrape a surface, or scan. Dash also reminds us that the tabula rasa refers to the eruption of Mount Pelée in 1902, here symbolising a moment of destruction that might pave the way for the creation of the new. The neologism of 'verrition', according to Dash, building in turn on James Clifford's reading of Césaire's 'politics of neologism', points 'to the fact that [this new order] would not be grounded in the languages of French or Creole; that is, it would not be

\footnotetext{
${ }^{37}$ See for example Raphaël Confiant, Aimé Césaire, une traversée paradoxale du siècle (Fort-de-France : Editions Stock, 1993).

${ }^{38}$ Aimé Césaire, Cahier d'un retour au pays natal, p. 132 ; p. 133.
} 
contaminated by history'. ${ }^{39}$ At the same time, however, in her recent study of negritude and modernist print, Carrie Noland notes that the term 'verrition' is used by Jean-Antelme BrillatSavarin to evoke the movement of the tongue to dislodge portions of food in the mouth, and goes on to show how the line serves to link poetry, the 'vers', with nourishment. ${ }^{40}$ The call for innovation intimated by Dash's reading, then, can be complemented with this added association of verse with sustenance, with energy and renewal. Césaire's own expansive language in the poem as a whole, as it evokes his circuitous and unfinished journey, both transcends cultural frontiers, and promises the renewal of poetry through the verses we have just read. This promise of ongoing movement, as well as the refusal of cultural categorisation, serves to dramatise the multilingual, multi-layered and continuous movement of return.

\section{Dany Laferrière, L'Enigme du retour}

Laferrière's L'Enigme du retour, published seventy years after Césaire's Cahier in 2009, is steeped in the former work. Laferrière's narrator repeatedly refers to Césaire, and always carries a creased old copy of the text with him when he travels. Laferrière's work, however, if less obviously linguistically diverse, nevertheless provides a reflective development of Césaire's Cahier in that it expresses and maintains a deeper ambivalence about the success of the poet's return. L'Enigme du retour can be read, as Lucy Brisley suggests, to a certain extent as nostalgic, as an expression of a desired recapturing of the land of origin as the writer comes to terms with the loss of his father. ${ }^{41}$ Brisley also suggests nevertheless that Laferrière's nostalgia is 'an ambiguous concept', which enables him to navigate the disjunction between past and present, rather than creating a crude distinction between the land of exile and a putative 'home'. ${ }^{42}$ I would add, moreover, that the text should be understood to be quite astute in its knowing detachment from the myth of return and in its simultaneous experimentation with and debunking of the language of reintegration and belonging. Most explicitly, perhaps, it is significant that Césaire's title word 'Cahier' is

\footnotetext{
${ }^{39}$ J. Michael Dash, The Other America: Caribbean Literature in a New World Context (Charlottesville: University Press of Virginia, 1998) p. 65. See also James Clifford, 'A Politics of Neologism: Aimé Césaire', The Predicament of Culture: Twentieth-century Ethnography, Literature, and Art (Cambridge: Harvard University Press, 1988), pp. 175-181.

${ }^{40}$ See Carrie Noland, Voice of Negritude in Modernist Print: Aesthetic Subjectivity, Diaspora, and the Lyric Regime (New York: Columbia University Press, 2015) p. 41.

${ }^{41}$ See Lucy Brisley, 'On the Vicissitudes of Nostalgia: Dany Laferrière's L'Enigme du retour' in Lee Skallerup Besette (ed.), Dany Laferrière: Essays on his Life and Works (Oakville: Guernica Editions, 2013) pp. 94-121.

${ }^{42}$ Ibid., p. 95, p. 114. Claude Cavallero also discusses this ambivalent relationship with exile and return in 'La Problématique du retour de l'exil dans les romans de Tahar Ben Jelloun Au pays et de Dany Laferrière L'Enigme du retour', Nouvelles Etudes Francophones 31.2 (2016) : 100-109.
} 
replaced here with the term 'Enigme', as if Laferrière does not so much track the return but rather muses openly on how that journey or process must remain unfathomable and incomplete. And while Césaire's linguistically eclectic return nevertheless concluded with the affirmation of the poet as leader reclaiming his native Martinique, in all its diversity, Laferrière's narrator's more tentative voice implies a more subdued and more doubtful kind of loosening of the relationship between language, identity, and the process of return. ${ }^{43}$

If Césaire's text opens with an expression of alienation and of a loss of belonging in the poet's native Martinique, then, Laferrière's is set in motion by the announcement of his father's death, alone in America, after many years of exile after he was forced to flee the dictatorship of Papa Doc Duvalier in Haiti. Having recorded the traumas of his sudden departure from Haiti after the assassination of his friend, Gasner Raymond, in Le Cri des oiseaux fous, Laferrière's narrator now attempts a return which, though refusing to dwell on the violent past, nevertheless remains steeped in mourning - for his father, but also for these other past losses. ${ }^{44}$ While the linguistic experimentation of the Cahier is a response to the silence of a population of exploited and down-trodden Martinicans, then, Laferrière's is triggered perhaps in part by the silencing imposed by successive dictators in Haiti but also by grief - a grief made all the more complex by the lack of regular contact even when his father was alive. Indeed, the linguistic richness and playfulness of L'Enigme du retour are palpably underpinned by loss, by the absence of the father and the son's difficulty in finding the words in which to mourn him, and though the bereavement induces the return to Haiti from Canada, the text actually seems more concerned with writing in the wake of grief than with a desire to reconnect straightforwardly with a putative origin. Martin Munro has suggested that the father's death 'brings to light and heightens an underlying anxiety over place and belonging', but one might argue at the same time that the narrator of L'Enigme is not committed to the notion of belonging. Rather, the return is a coming to terms with the father's death, with the loss of intimacy with him when he was alive, and with himself as necessarily multiple, rootless and diasporic. ${ }^{45}$ Reading Césaire is crucial for Laferrière's narrator, then, not so much because the text inspires him to return but because, 'le poète m'aide à faire le lien entre

\footnotetext{
${ }^{43}$ Yolande Aline Helm discusses Laferrière's desacralisation of the poet figure in ' $"$ Je navigue dans deux temps» : errance spatiale et identitaire dans L'Enigme du retour de Dany Laferrière', Etudes caribéennes 37-8 (2017). Helm does not, however, specifically discuss the construction of return through language.

${ }^{44}$ See Dany Laferrière, Le Cri des oiseaux fous (Paris: Zulma, 2015. See also Jana Evans Braziel, Duvalier's Ghosts: Race, Diaspora, and US Imperialism in Haitian Literatures (Gainesville: Florida, 2010) for an erudite reading of Laferrière's text.

${ }^{45}$ Martin Munro, 'Exile, Return, and Mourning in Aimé Césaire's Cahier d'un retour au pays natal and Dany Laferrière's L'Enigme du retour', Irish Journal of French Studies 13 (2013): 87-109.
} 
cette douleur qui me déchire et le subtil sourire de mon père' ['the poet helps me to link this pain that tears me apart with my father's subtle smile']. ${ }^{46}$ Césaire the father of Caribbean letters, moreover, becomes blurred with the narrator's own father in his dreams. And if he notes that the former poet's discovery of 'des territoires inédits dans cette aventure du langage' ['uncharted territories in this adventure of language'] allowed him to transcend his anger against the coloniser, then perhaps his own linguistic adventure is a way for him to reflect obliquely on other unnarratable traumas - the oppression of his compatriots, his separation from his exiled father, and eventually, the father's death. ${ }^{47}$ The literary selfconsciousness of these references to Césaire, as well as to other literary influences and to his own work, are also, as Gabriel Parker suggests, a reminder that the narrator seeks as much a 'literary homeland' as a reconnection with the place of his birth. ${ }^{48}$

While Césaire's Cahier opens with a proliferation of images of a diseased Martinique, stultified and prevented from speaking out by crippling hunger, Laferrière's L'Enigme opens with another kind of silence. After receiving a telephone call informing him of his father's death, the narrator recalls a line from Césaire, 'la mort expire dans une blanche mare de silence' ['death expires in a white pool of silence'], describing the death of the leader of the Haitian slave revolt, Toussaint Louverture, in prison in the snowy landscape of the French Jura. ${ }^{49}$ The colour white in this passage from the Cahier represents obliteration by the white man, and in L'Enigme the peaceful landscape of a frozen Quebec reminds the narrator of his father's silencing in exile at the same time as it serves to figure his struggle in the early pages to find words to express his grief. The snow here is not, as it was in Césaire, a metaphor for colonial annihilation, but it does connote a repression of emotion; the narrator's first response to the call is to drive around the deserted landscape and observe its silence, so that 'à force de nourrir ce silence / le vide s'est emparé de lui / et l'homme n'est plus qu'un arbre sec / qui craque dans la neige' ['by nourishing this silence / emptiness took hold of me / and man is no more than a dried out tree / which cracks in the snow']. ${ }^{50}$ The short, abrupt lines of Laferrière's verse emphasise the inadequacy of language in the face of grief. This linguistic sparsity recurs later, when the narrator attempts to write about his father's exile, and the brief

\footnotetext{
${ }^{46}$ Dany Laferrière, L'Enigme du retour (Paris: Grasset \& Fasquelle, 2009) p. 58. Translations from this text are my own.

${ }^{47}$ Ibid., p. 58.

${ }^{48}$ Gabriel Parker, “'Returns to the Native Land”: Dany Laferrière's Unresolved Dilemma', in Lee Skallerup Besette (ed.), Dany Laferrière: Essays on his Life and Works (Oakville: Guernica Editions, 2013) pp. $72-93$ (p. 83). See also Yolaine Parisot, 'Sous les yeux du père, lire le Cahier comme une proposition de retour sur l'enigme Laferrière', Etudes françaises 52.1 (2016) : 91-106.

${ }^{49}$ Dany Laferrière, L'Enigme du retour, p. 14.

${ }^{50}$ Ibid., p. 15.
} 
lines of verse, mirror his lack of communication with his father as well as the father's solitude, and the broader crushing of dissidents in Haiti of which the father is just one example: 'mon père a passé / plus de la moitié / de sa vie / hors de sa terre / de sa langue / comme de sa femme' ['my father spent / more than half of his life / apart from his land / from his language / as from his wife']. ${ }^{51}$ Again, the Cahier serves to link these parallel silences, as the narrator imagines his father reading Césaire's imagery of the 'foule criarde étonnamment passée à côté de son cri' ['the shrill crowd astonishingly cut off from its cry'], and connects the oppressed Martinican city both with his father's loss of voice in exile and with the stifled city of Port au Prince. ${ }^{52}$

The narrator's return to Port au Prince in the second section, however, responds to this silencing with a varied concatenation of images and stimuli. Alongside Césaire, Laferrière's title references V.S. Naipaul's The Enigma of Arrival, a similarly linguistically vibrant attempt to record the writer's immersion in a new landscape - in this case in rural England. The movement here from South to North, from Trinidad to Wiltshire, is in some ways the converse of Laferrière's trip from Montreal to Port-au-Prince, and later, to his father's village, but like Naipaul's richly descriptive prose, Laferrière's alternating verse and prose passages describing the arrival in Port-au-Prince seek to capture and bring together multiple details of human and natural life in the new environment. If return was also coupled with departure in Césaire, the echoing of Laferrière's return with Naipaul's arrival serves again to blur different forms of movement and to figure the return as a multifaceted and ongoing rediscovery rather than a retrogressive step. After the silencing represented by the frozen landscape of Quebec, then, Port-au-Prince is noisy and colourful, though the vivid impressions that Laferrière's narrator captures are in no way idealised but rather embrace the eclecticism of the rediscovered urban landscape. Out of the language of emptiness and loss burgeons an 'explosion de couleurs / d'odeurs et de saveurs tropicales' ['an explosion of colours / of smells and tropical flavours']. ${ }^{53}$ Unlike Césaire's languishing Fort-de-France, Laferrière's city is full of life and movement, and the language is concomitantly one of effervescence and proliferation, reminiscent of a multi-coloured painting: 'couleurs primaires / Dessins naïfs. / Vibrations enfantines. / Aucun espace vide. / Tout est plein à ras bord. / La première larme fera déborder / ce fleuve de douleurs dans lequel / on se noie en riant' [primary colours / naive drawings. / Childish vibrations. / No empty space. / Everything is

\footnotetext{
${ }^{51}$ Ibid., p. 63.

52 Ibid., p. 64.

${ }^{53}$ Ibid., p. 78.
} 
completely full. / The first tear will make this river of pain in which people drown while laughing overflow]. ${ }^{54}$ Although Laferrière's lines are once again curtailed and succinct here, they nevertheless convey sound and activity, a restless agitation, blending melancholy with laughter. Such briefly evocative verses are interspersed, moreover, with sometimes real and sometimes imagined anecdotes based on characters observed by the narrator, as the poetics of the city mingles sensory impressions with stories of human behaviour. Importantly, these verses record discordance far more than they promise reintegration, and Laferrière's project seems to be to capture the immediate impression of this discordance rather than to theorise or analyse.

If Césaire juxtaposed the language of the city with that of nature, moreover, Laferrière brings these two sets of imagery together. The narrator bathes in the noise, the dust and grime of the city but sets it alongside references to the heat of the sun, the smell of over-ripe fruit, the scuttling of the lizard. This combination does not connote a dichotomy between the real city and the fantasy of rural immersion, but rather a simultaneous confrontation with competing images, sounds and smells. While in the Cahier passages evoking the city are juxtaposed with those affirming the integration of the poet in the natural environment, Laferrière's text mingles the language of the city with the language of nature more explicitly and more tightly. The literary and artistic representation of this stimulating world is also not cut off from its reality but, the narrator hopes, immersed in it even as it reshapes it, and he embraces the environment to which he returns using a medley of different kinds of both concrete and more aesthetically sculpted imagery. Far from falling into either nostalgia or disgust, Laferrière's narrator's language precisely seeks to capture in its own variety the multiple resonances of the world he rediscovers. Elaine Savory's exploration of Derek Walcott's 'language of plants' might resonate similarly, then, with Laferrière, as she notes, 'like vegetation, language can be overgrown, withered, lush, fragile or full of new life, conventional, repetitive, or newly apprehended despite familiarity'. ${ }^{55}$ To grasp the multiple facets of the Haitian capital, Laferrière's narrator employs a comparable stylistic and lexical eclecticism.

\footnotetext{
${ }^{54}$ Ibid., p. 82. On Laferrière's use of painting, see Jean Hérald Legagneur, 'L'Enigme du retour de Dany Laferrière ou quand imaginaire et urgence du social se transforment en Cahier du retour au pays natal', Voix plurielles 10.2 (2013): 295-311.

${ }^{55}$ Elaine Savory, 'Derek Walcott's Language of Plants', in Elizabeth DeLoughrey and George B. Handley (eds.), Postcolonial Ecologies: Literatures of the Environment (Oxford: Oxford University Press, 2011) pp. 8094 (p. 93).
} 
More specifically, Laferrière's language of return resonates with a cacophony of local sounds, which interrupt his own reflective descriptions. In recounting his return to his mother's house, for example, her singing joins his own poetic reflection and he inserts fragments of her songs into his writing, 'ce chant de ma mère dont / j'ai fini par capter quelques bribes, / parle de marins paniqués, / d'une mer mouvementée / et d'un miracle au moment où / tout espoir semblait perdu' [this song of my mother's / of which I have managed to capture a few fragments / speaks of panicked sailors / of a turbulent sea / and of miracle at the moment when all hope seemed lost]. ${ }^{56} \mathrm{~A}$ few pages later, he notes, 'c'est par le bruit que la Caraïbe / est entrée en moi' ['it is through noise that the Caribbean / entered into me'], and he insists (perhaps like Baudelaire again, though this time in his incarnation as poet of the city) that his art seeks to immerse itself in the crowd with all its noisy energy. ${ }^{57}$ The anecdotes of passersby are at the same time interrupted by the abrasive but cheerful insistence of drivers hooting their horns, capturing another singular form of expressiveness - 'interdire le klaxon à Port-au-Prince serait de la censure' ['to prohibit beeping one's horn in Port-au Prince would be a form of censorship']. ${ }^{58}$ Music blares from the windows of the passing traffic, cutting across the hum of voices in the streets. Local sounds and voices, however, do not in any way connote a particularised community, and Laferrière, no more than Césaire, does not associate the return to and rediscovery of Martinique or Haiti with an affirmation of Creole language and culture. When curious children surround the narrator as if he were a stranger, addressing them in Creole does nothing to convince them that he is Haitian.

Conversely, the character most protective of the Creole language in Laferrière's text is the Irish wife of one of his friends, who has clearly become more at home in Haiti than in Ireland. Laferrière is ironically debunking here again the idea of any originary monolingualism, narrating his return to Haiti in a French resonating with visual and auditory diversity and presenting the affirmation of cultural identity as a matter of free personal choice rather than of roots. His famous uncoupling of identity, nationality and culture is most starkly performed in the playful narrative Je suis un écrivain japonais, but is also evident in his casual engagement with Creole here.

After this conjuring of the cacophony of the Haitian city, Laferrière's narrator travels to his father's village, and this further step back in the apparent return to origins is expressed by an embrace of the language of the rural environment, again as if in a return to 'nature'.

\footnotetext{
${ }^{56}$ Dany Laferrière, L'Enigme du retour, pp. 111-112.

57 Ibid., p. 122.

58 Ibid., p. 133.
} 
Yet, as I have suggested, this is not so much an embrace of the natural as opposed to the urban as a further celebration of human immersion in the environment. The narrator earlier conceived his description of the city as a kind of organic connection, as if ' $\mathrm{j}$ ' ai tant écrit, je n'ai plus l'impression d'être un écrivain mais un arbre dans la forêt' ['I've written so much that I no longer have the impression that I am a writer but rather a tree in the forest' $].{ }^{59} \mathrm{On}$ the journey out to the village, moreover, the narrator again seeks to blend with nature, 'pour me fondre / dans la nature / et devenir une feuille, / un nuage / ou le jaune de l'arc-en-ciel' ['to melt into nature, to become a leaf, a cloud, a the yellow in the rainbow'], but this is succeeded by attention to the human poverty he witnesses, juxtaposed once again with a reference to the disenfranchised Martinicans evoked by Césaire in the Cahier. The sensual details of the setting do not in any way provide the apparently longed-for sense of origin, however, but rather surround the emptiness of the private funeral ceremony he undertakes in his father's village. The narrator becomes powerfully conscious of his place in his natural surroundings, but this provides not a sense of belonging but a more disorientating lightness, ‘je me sens tout à coup léger. / Le ciel n'est pas plus loin / que cette feuille de bananier / que ma tête frôle' ['I suddenly feel light. / The sky is no farther away / than that banana leaf / that brushes against my head']. ${ }^{60}$ In a reference back to the work's title, the return to the father's village is precisely 'énigmatique', not a rerooting but a disconcerting discovery, an alertness to local sights and sounds, and the invention of a language in which to capture them. This language consists in the seizing of sensual details, fragments of human, animal and plant life, but whilst the narrator seeks to conjure their immediacy he at the same time continues to resist at once the myth of originary belonging and that of natural purity. The narrator may also seek to capture in language the multiple sensory effects of that return but these are conveyed precisely as subtle, elusive, and always mediated by a self-conscious literary imagination. Indeed, this very scene of immersion includes a self-conscious reference to the evening glow evoked in Baudelaire's 'Le Balcon' - also his father's favorite poem, and conjuring again the opening of the return section of L'Enigme on the balcony of the hotel.

These evocations of environmental features are nevertheless at times associated in L'Enigme du retour, and elsewhere in Laferrière's work, with the aspiration towards a 'langage primitif', stripped of artifice and unadorned, that would accomplish the writer's immersion. The narrator wants to 'voir un jour les choses / dans leur beauté nue' ['to one day

\footnotetext{
${ }^{59}$ Ibid., p. 152.

${ }^{60}$ Ibid., p. 267.
} 
see things in their naked beauty'], though he is ultimately 'pas sûr d'être / dans un temps réel / en m'avançant vers / ce paysage longtemps rêvé' ['not sure whether I am in real time, while moving towards this landscape of which I have for a long time dreamed']. ${ }^{61}$ Certainly, some of the verse passages in L'Enigme retain a kind of sparsity that seems to bring them closer to the referents they seek to capture, and the references to the writer blurred with his physical environment imply an idea of a literary writing capable of capturing the world without the distortion created by artifice. In an earlier work, Pays sans chapeau, Laferrière also recounts a return to Haiti, though not this time with the same anguish triggered by his father's death, and here the idea of the 'écrivain primitif' is elaborated explicitly: 'je n'écris pas, je parle. On écrit avec son esprit. On parle avec son corps. Je ressens ce pays physiquement' ['I don't write, I speak. You write with your mind. You speak with your body. I feel this country physically']. ${ }^{62}$ Primitive writing would be, then, this unmediated and physical language, a direct transcription of sensual experience rather than a linguistic reshaping. Nevertheless, Laferrière is quite conscious that, despite this aspiration towards a purer expressiveness, primitive language is an illusion, reminiscent of Césaire's verbal summoning of the landscape and all the flora and fauna within it, but unable to provide the writer's desired transparency. At the end of Pays sans chapeau, moreover, the narrator admits that the 'pays réel' and the 'pays rêvé' are indistinguishable; the sensual world is always filtered through the aesthetic imagination. The return is also again here, as Anne-Gaëlle Saliot argues in her reading of Pays sans chapeau alongside Le Cri des oiseaux fous, the discovery of 'une identité multiple, fluctuante qui ne se modèle plus sur les récits d'origine' ['a multiple, fluctuating identity, not modelled on narratives of origin']. ${ }^{63}$ Rather than rediscovering a homeland, it is significant in addition that what both Césaire and Laferrière discover is their immersion in writing itself. These evocations of return finish by championing not so much a language that would be at one with the world, and with the place of origin, as a symphony of sounds, a medley of images created in writing, the discordant energy of which capture something of the multidimensional process of return rather than resettlement.

Beneath both Césaire and Laferrière's linguistically dynamic poetics of return, there lingers, then, a persistent sense of uncertainty. Both are tempted by fantasies of a language that could unite human and environment, but both refuse to associate that language with an

\footnotetext{
${ }^{61}$ Ibid., p. 278.

${ }^{62}$ Dany Laferrière, Pays sans chapeau (Québec: Lanctôt, 1999) p. 13.

${ }^{63}$ See Anne-Gaëlle Saliot, 'Le Cri des oiseaux fous et Pays sans chapeau de Dany Laferrière: départ, retour, rabordaille', Nadève Ménard (ed.), Ecrits d'Haïti: perspectives sur la littérature haïtienne contemporaine (1986-2006) (Paris: Editions Karthala, 2011) pp. 421-434 (p. 434).
} 
Edenic paradise or with a myth of secure homecoming. The 'return' to nature connotes neither mastery nor idyllic harmony, but an awareness of the interdependence of human activity with ecological forces, and, moreover, the language of immersion is also subjected to a kind of self-conscious internal critique. As I have suggested, the poetics of return is more an eclectic experiment with various kinds of language, as well as with a range of literary forms and references, than a reuniting with origins, couched in a monolingual mother tongue. Both writers are also skeptical of figuring Creole as the language of return, and include only passing references to Creole language and lexicon, preferring to position their creative work outside national and cultural frontiers. Laferrière may use Creole proverbs as epigraphs to the chapters of Pays sans chapeau, but it is striking that, again, these are deliberately presented as somewhat opaque, to allow the reader to appreciate not only popular wisdom but also 'la fertile créativité langagière haïtienne' ['fertile Haitian linguistic creativity'] . ${ }^{64}$ Many of the proverbs also contain images, once again, of the blurring between departure and return (for example, 'pati pas di ou rivé pou ça'. Partir ne veut pas dire que tu es arrivé pour autant' ['leaving does not also mean that you arrive']). ${ }^{65}$ The title Pays sans chapeau refers, moreover, to the 'pays des morts' ['the land of the dead'], and this reference to death as a backdrop to the writer's linguistic experiment is clearly also one that shapes Césaire's traumatic reckoning with colonial history in the Cahier and Laferrière's mourning for his father, as well as for all the Haitians silenced by successive dictators, in L'Enigme $d u$ retour. These reminders of a history of oppression and violence serve to draw attention to the silence that underpins the linguistic energy of Césaire and Laferrière's writing, and to suggest that the languages they juxtapose are always provisional and contingent; there are losses they cannot recuperate. While Césaire's epic poem ends ultimately with an affirmative vision for a new future and for a new poetry, however, Laferrière's playful literary narrative finishes with a more stark admission of its linguistic contingency and of the writer's lack of a sense of rootedness. The later work is less optimistic about the power of the poetry of return, and less celebratory of the poet's linguistic experimentation. The writing of return in both cases demands the juxtaposition of different forms of language: a kind of multilingual writing experiment within an apparently monolingual French work. Laferrière's more doubtful vision of the writing of return testifies nevertheless to a perhaps yet more radical dissociation between both narrative and poetry, and the myth of origins.

\footnotetext{
${ }^{64}$ Dany Laferrière, Pays sans chapeau, p. 7.

65 Ibid., p. 51.
} 